\title{
Nekrobiosis Lipoidica in a Pediatric Patient
}

\section{Gözde Emel Gökçek ๑ Özge Şeyda Saka ๑ Emine Çölgeçen ${ }^{\odot}$ Murat Borlu $\odot$ Özlem Canöz $\odot$} Pediatrik Bir Hastada Nekrobiyozis Lipoidika

ABSTRACT

Necrobiosis lipoidica is a rare chronic granulomatous disease that has historically been associated with diabetes mellitus, but recently it is thought to be secondary to microangiopathic changes. We report a necrobiosis lipoidica case of a five-year-old girl with diabetes since the age of two, because it is exceptionally unusual in pediatric diabetes. Necrobiosis lipoidica should be considered in pediatric patients with slowly expanded erythematous plaques and patches. This will help protect the patient from other important diabetic microangiopathic complications, such as nepropathy and retinopathy and also malignant progression, such as squamous cell carcinoma.

Keywords: Necrobiosis lipoidica, type 1 diabetes, children, diabetes, granulomatous dermatitis

öz

Nekrobiyozis lipoidika, tarihsel olarak diabetes mellitus ile ilişkilendirilmiş olan, ancak son zamanlarda mikroanjiyopatik değişikliklere ikincil olduğu düşünülen, nadir görülen kronik granülomatöz bir hastalıktır. Bu yazıda, iki yaşından beri diyabeti olan, beş yaşındaki bir kız çocuğunda görülen nekrobiyozis lipoidika vakasını sunuyoruz, çünkü nekrobiozis lipoidika pediatrik diyabette nadir görülen bir durumdur. Yavaş yavaş genişleyen, eritemli plak ve yamaları olan pediyatrik hastalarda, nekrobiyozis lipoidika ayırıcı tanıda muhakkak düşünülmelidir. Böylece hastanın nepropati ve retinopati gibi diğer önemli diyabetik mikroanjiyopatik komplikasyonlardan ve ayrıca skuamöz hücreli karsinom gibi malign dönüşümlerden korunmasına yardımcı olabiiriz.

Anahtar kelimeler: Nekrobiyozis lipoidika, tip 1 diyabet, çocuk, diyabet, granülomatöz dermatit
Received: 12.10 .2020

Accepted: 13.11 .2020

Published Online: 30.04 .2021

Cite as: Gökçek GE, Saka ÖŞ, Çölgeçen E, Borlu M, Canöz Ö. Nekrobiosis lipoidica in a pediatric patient. İzmir Dr. Behçet Uz Çocuk Hast. Dergisi. 2021;11(1):113-6.

Gözde Emel Gökçek Yozgat Bozok Üniversitesi Tıp Fakültesi Deri ve Zührevi Hastalıkları Anabilim Dalı Yozgat - Türkiye

gozdegorek89@hotmail.com ORCID: 0000-0003-1067-6795

ö. Ş. Saka 0000-0002-5316-0580 Kayseri Şehir Hastanesi Deri ve Zührevi Hastalıkları Anabilim Dalı Kayseri, Türkiye

E. Çölgeçen 0000-0001-9651-6068 Yozgat Bozok Üniversitesi Tıp Fakültesi Deri ve Zührevi Hastalıkları Anabilim Dalı Yozgat, Türkiye

M. Borlu 0000-0003-0824-490X Erciyes Üniversitesi Tıp Fakültesi Deri ve Zührevi Hastalıkları Anabilim Dalı, Kayseri, Türkiye

Ö. Canöz 0000-0002-0200-6970 Erciyes Üniversitesi Tıp Fakültesi Patoloji Anabilim Dalı Kayseri, Türkiye

\section{INTRODUCTION}

Necrobiosis lipoidica (NL) is an uncommon chronic granulomatous disease traditionally linked to diabetes mellitus (DM). Recent studies have shown that microangiopathy is significantly involved in the pathogenesis of NL. Patients with NL present with erythematous papules and atrophic telangiectatic patches, especially on the lower extremities. Necrobiotic xanthogranuloma, granuloma annulare and other granulomatous diseases should be considered at differential diagnosis. Biopsy is also useful during diagnosis ${ }^{(1)}$. NL occurs in $\sim 75 \%$ of patients with clinical DM or in whom DM will develop subsequently, but it is unusual in paediatric diabetes. However, NL in paediatric patients is linked to an increased risk of diabetic nephropathy and retinopathy ${ }^{(2)}$, such that its diagnosis is of particular importance. We describe a diabetic patient with NL and discuss the case in light of previous reports in

(c) Copyright İzmir Dr. Behçet Uz Children's Hospital. This journal published by Logos Medical Publishing

Licenced by Creative Commons 4.0 International (CC BY) 


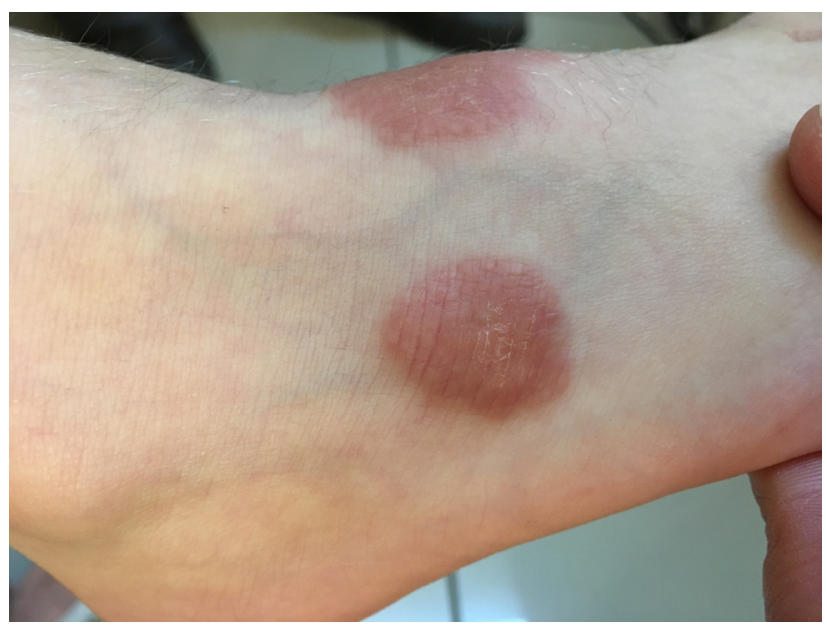

Figure 1. Circular, indurated red plaque, measuring $1 \times 0.8 \mathrm{~cm}$ on foot.



Figure 2. The other well-defined, indurated red plaque, measuring $2 \times 2 \mathrm{~cm}$ on dorsum of foot.

the literature.

\section{CASE REPORT}

A 5-year-old girl with type $1 \mathrm{DM}$ diagnosed at the



Figure 3. Degenerated collagen fibers containing CD 68 (+) epithelioid histiocytes and middle necrotic, locally multinuclear giant cells.

age of 2 years developed diabetic ketoacidosis. She had no family history of DM and was being followedup by the paediatric endocrinology department of our hospital. Her HbA1c value was 7.8. She had undergone annual screening for microangiopathic complications, but neither microalbuminuria nor retinopathy was detected. The patient's diabetes was currently under control with insulin. Two distinct, persistent plaques, both containing a depressed central area and an elevated purple peripheral ring, were observed on the top of her right foot. One of the lesions appeared as a circular, indurated red plaque $1 \mathrm{~cm} \times 0.8 \mathrm{~cm}$ in size (Figure 1 ) and the other as a $2 \mathrm{~cm} \times 2 \mathrm{~cm}$ red plaque (Figure 2). Both plaques began as painless, reddish papules which gradually expanded to form plaques over a 6-month period.

Biopsy of the plaques from the superficial to deep dermis led to a diagnosis of NL, based on the presence of degenerate collagen fibres containing CD 68 (+) epithelioid histiocytes and moderately necrotic, multinuclear giant cells (Figure 3).

The plaques were successfully treated, resolving almost completely in response to 1 week of topical steroid therapy.

\section{DISCUSSION}

Necrobiosis lipoidica is a chronic granulomatous dermatosis with a reported prevalence among dia- 
betic adults of $0.3 \%$. However, it may also occur in patients in whom no indication of impaired glucose metabolism is observed. NL is particularly frequently seen in women, with the onset generally occurring in early or middle adulthood ${ }^{(1)}$. There are only a few case reports of NL developing in childhood. However, it developed in our 5-year-old patient with DM.

$\mathrm{NL}$ is an idiopathic entity that has been attributed to vascular disruption involving immune complex deposition or microangiopathic changes concluding with collagen degradation ${ }^{(3)}$.

Although NL is more common in diabetic patients, it is not pathognomonic for DM. Özkur et al. ${ }^{(4)}$ described a non-diabetic 14-year-old girl who presented with an asymptomatic, $7 \mathrm{~cm} \times 5 \mathrm{~cm}$, single red plaque located in the interscapular region that had gradually enlarged over 5 years. Our patient had two distinct, persistent plaques, both containing a depressed central area and an elevated purple peripheral ring, on the top of her right foot.

Reports of a link between NL and diabetes in the paediatric age group are limited. Dereci et al. ${ }^{(5)}$ described the case of a 13-year-old girl with type $1 \mathrm{DM}$ who presented with a slowly enlarging erythematous patch on her leg. The patient's blood glucose level was not under control despite subcutaneous insulin treatment. After topical steroid therapy and glucose control, the lesion resolved, as in our patient.

Marchetti et al. ${ }^{(6)}$ reported a case of granuloma annulare involving the bilateral ankles and NL in the left pretibial region in a 12-year-old girl, both of which appeared prior to a diagnosis of maturityonset diabetes of the young (MODY). Following a detailed analysis of similar cases reported in the literature, the authors conclude that NL is more common in type $1 \mathrm{DM}(6.5 \%)$ and MODY (2.8\%) than in type 2 DM (0.4\%). Our patient had been diagnosed with type $1 \mathrm{DM}$ at 2 years of age.

Paediatric patients are more likely to develop severe complications and morbidity secondary to NL. Ulceration, sometimes with subsequent infection, is seen in $25-33 \%$ of patients with NL. Although malignant ulceration is a rare entity, it should nevertheless be suspected in the event that the ulcer fails to resolve with conservative treatment. This was the case in a 28-year-old woman with type $1 \mathrm{DM}$ who presented with established DM, with a history of squamous cell carcinoma in a region of NL involvement 11 years previously ${ }^{(7)}$. Neither ulceration of the plaques nor malignancy developed in our patient, but further follow-up would be advisable.

In their study of children with NL, Verroti et al. ${ }^{(8)}$ found a higher prevalence of persistent microalbuminuria and retinopathy in those with NL compared to those without NL. The authors concluded that NL may be a clue to the presence of nephropathy and retinopathy, both in children and adults. Neither of these pathologies were detected in our patient.

The treatment of NL may be problematic and is often unsuccessful. Topical or intralesional steroids have been shown to be capable of ameliorating inflammation and sclerosis. Other alternatives include the use of systemic hydroxychloroquine, antiplatelet agents, cyclosporine, thalidomide, clofazimine, anti-tumour necrosis factor agents, fumaric acid esters, PUVA or UVA1 photodynamic therapy, tacrolimus and pentoxifylline. In our patient, the plaques responded well to topical steroid therapy. Given the long-term risk in NL of malignant progression to squamous cell carcinoma, patients should be followed up intermittently after treatment.

\section{CONCLUSION}

$\mathrm{NL}$ is a chronic degenerative disease of unknown aetiology involving the dermal connective tissue. It is mostly seen in diabetic patients, especially adults. However, it should also be considered in paediatric patients who present with slowly enlarging erythematous plaques and patches. The early identification and treatment of NL may aid the prevention of other diabetic microangiopathic complications as well as ulceration of the lesions and subsequent squamous cell carcinoma development.

Conflict of Interest: The authors report no conflict of interest.

Informed Consent: The patient's parents in this manuscript had given written informed consent to the publication of their case details. 


\section{REFERENCES}

1. Reid SD, Ladizinski B, Lee K, Baibergenova A, Alavi A. Update on necrobiosis lipoidica: a review of etiology, diagnosis, and treatment options. J Am Acad Dermatol. 2013 Nov;69(5):78391. https://doi.org/10.1016/j.jaad.2013.05.034

2. Lause M, Kamboj A, Fernandez Faith E. Dermatologic manifestations of endocrine disorders. Transl Pediatr. 2017;6(4):300-12.

https://doi.org/10.21037/tp.2017.09.08

3. Sibbald C, Reid S, Alavi A. Necrobiosis lipoidica. Dermatol Clin. 2015 Jul;33(3):343-60. https://doi.org/10.1016/j.det.2015.03.003

4. Özkur E, Hasçiçek SÖ, Altunay IK. Atypical presentation of necrobiosis lipoidica in a pediatric patient. Pediatric Dermatology. 2019 Jan;36(1):e31-e33. https://doi.org/10.1111/pde.13716

5. Dereci S, Pirgon O. Necrobiosis Lipoidica. Indian Pediatrics. 2016;53(9):848.

6. Marchetti F, Gerarduzzi T, Longo F, Faleschini E, Ventura A, Tonini G. Maturity-onset diabetes of the young with necrobiosis lipoidica and granuloma annulare. Pediatr Dermatol. 2006;23(3):247-50.

https://doi.org/10.1111/j.1525-1470.2006.00227.x

7. Gudi VS, Campbell S, Gould DJ, Marshall R. Squamous cell carcinoma developing in necrobiosis lipoidica diabeticorum: a case report. Clin Exp Dermatol. 2000;25(8):597-9. https://doi.org/10.1046/j.1365-2230.2000.00715.x

8. Verotti A, Chiarelli F, Amerio P, Morgese G. Necrobiosis lipoidica diabeticorum in children and adolescents: a clue for underlying renal and retinal disease. Pediatr Dermatol. 1995;12(3):220-3.

https://doi.org/10.1111/j.1525-1470.1995.tb00162.x 